\title{
Origin and metamorphic evolution of magnesite-talc and adjacent rocks near Gemerská Poloma, Slovak Republic
}

\author{
Kristína PETRASOVÁ1, Shah Wali FARYAD2², Petr JEŘÁBEK2,3, Eliška ŽÁČKOVÁ ${ }^{2,3}$ \\ ${ }^{1}$ Department of Geology and Mineralogy, Technical University Košice, Park Komenského 15, 04384 Košice, Slovak Republic \\ ${ }^{2}$ Institute of Petrology and Structural Geology, Charles University, Albertov 6, 12843 Prague 2, Czech Republic; faryad@natur.cuni.cz \\ ${ }^{3}$ Czech Geological Survey, Klárov 3, 11821 Prague 1, Czech Republic \\ ${ }^{*}$ Corresponding author
}

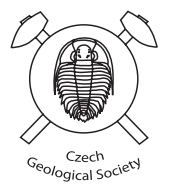

\begin{abstract}
Magnesite and talc deposit Gemerská Poloma is located in Early Palaeozoic rocks of the Gemericum, Slovakia. It experienced both Variscan and Alpine greenschist-facies regional metamorphism and was overprinted by contact metamorphism connected with the intrusion of a Permian granite. As the origin of talc in Mg-carbonate rocks from this locality is interpreted as a result of either regional or contact metamorphism, relation of talc formation to these two processes is critically discussed. The estimated P-T conditions $\left(6-7 \mathrm{kbar}\right.$ at $\left.400^{\circ} \mathrm{C}\right)$, reached during Alpine metamorphism, were obtained from the Permian metagranite that was not affected by the Variscan metamorphic event. The calculated P-T conditions were verified using various thermobarometers and pseudosections for biotite- and garnet-bearing assemblages in the metagranite.
\end{abstract}

Keywords: talc-magnesite deposit, metamorphism, P-T, Gemericum, Western Carpathians, Slovakia Received: 16 October 2006; accepted 12 March 2007; handling editor: V. Janoušek

\section{Introduction}

The Early Palaeozoic of the Gemericum is represented by three tectonic groups of different lithology and/or metamorphic conditions. From the top to bottom they are (Fig. 1): the Klatov Group formed mostly by gneisses and amphibolites, the Rakovec Group consisting of phyllites and metabasites and the Gelnica Group characterized by various types of phyllites and metamorphosed volcanic rocks of rhyolitic, and less frequently of basaltic, composition. In contrast to the Rakovec Group, the Gelnica Group contains large amounts of black schists-phyllites with lenses of carbonate rocks (Snopko 1967; Grecula 1982; Bajaník et al. 1983). Both groups underwent greenschist-facies metamorphism during Variscan and Alpine events (Varga 1973; Dianiška 1983; Faryad 1995). Weak thermal overprint in the central part of the Gelnica Group probably resulted from an intrusion of Permian granites (Kovách et al. 1986; Poller et al. 2000).

Magnesite-talc rocks at Dlhá Dolina Valley near the village of Gemerská Poloma were found by geological exploration (Malachovský et al. 1992). These rocks are part of the carbonate- and lydite (black cherts)-bearing sequence of the Gelnica Group (Grecula 1982). There are at least two models explaining the origin of magnesite and talc formation at the studied locality. Radvanec et al. (2004) proposed magnesite formation from limestone by infiltrated $\mathrm{MgCl}_{2}$ brines of evaporitic origin, mobilized during Variscan regional metamorphism. These authors supposed transformation of magnesite into talc during Alpine metamorphism. In contrast, talc formation by contact and metasomatic process was assumed by Malachovský et al. (1992), Kilik (1997) and Turanová et al. (1997). Dianiška (1983) described low-temperature hornfelses, various types of metasomatic alterations and spotted phyllites in the Dlhá Dolina area.

In this work we present mineral compositions of the talc-bearing assemblage and discuss possible relation of the talc formation to the granite magmatism. We focus specifically on the degree of Alpine overprint in this area. The last question is addressed using mineral assemblages from granite rocks that, based on textural relations and geochronological data, experienced only the Alpine metamorphism. Character and degree of the Alpine metamorphism in the Veporicum and western part of the Gemericum was discussed already by Vrána (1964, 1980). He was the first, who recognized the presence of Alpine chloritoid and kyanite in phyllites and gneisses, as well as of metamorphic garnet in granite. This author also stressed the pressure-dominated character of the Alpine metamorphism in this area. Garnet of similar composition was later found in the Gemericum granite (Faryad and Dianiška 1989; 1999) and thermobarometric calculation used for garnet-bearing assemblage confirmed $\mathrm{P}-\mathrm{T}$ conditions similar to those proposed by Vrána (1980). To verify $\mathrm{P}-\mathrm{T}$ estimates of Alpine metamorphism by independent methods, $\mathrm{P}-\mathrm{T}$ section is constructed for phlogopite-bearing mylonitized metagranite. 


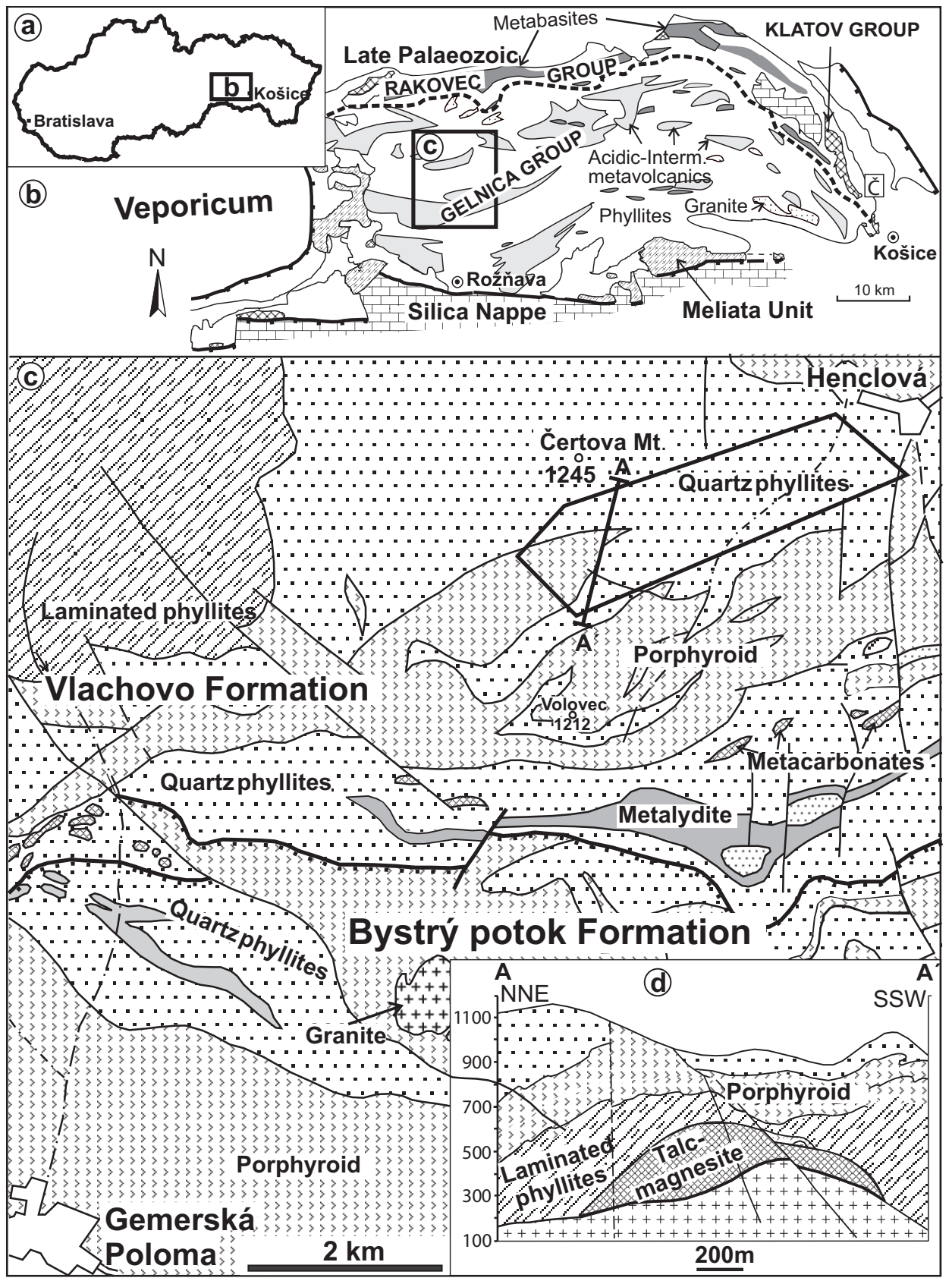

Fig. 1 Location (a) and schematic geological map of the Gemericum (b). Thick dashed line separates the Rakovec and Gelnica groups. Geological map of the Gelnica Group between Gemerská Poloma and Henclová (c) is from Bajaník et al. (1983) and Kilík (1997). Phyllites of similar composition but derived from sediments of different lithofacies of the Bystrý Potok and Vlachovo formations are hatched by the same pattern for simplification. Geological profile (d) cross-cutting the talc-Mg-carbonate body and surrounding rocks (Kilík 1997) is also shown.

\section{Geological setting}

A W-E trending magnesite-talc lens occurs near Gemerská Poloma, in the central part of the Gemericum between Dlhá Dolina and Henclová valleys (Fig. 1). It is part of the Lower Palaeozoic sequence of the Gelnica Group that comprises metamorphosed psammitic and pelitic sediments of either the Vlachovo and Bystrý potok formations (Cambrian-Silurian) according to Bajanik et al. (1983), or the Betliar and Smolník formations (Silurian?-Middle Devonian) according to Grecula (1982). Detailed field study of the Vlachovo Formation in the Dlhá Dolina Valley (Fig. 1, Dianiška 1983; Kilík 1997) indicated the presence of three lithofacies that are, from top to bottom, represented by: 1) Metamorphosed flysch sediments, i.e. rhythmically alternating pelites and psammites. These occur in the central and northern parts of the deposit and show a gradual transition to the underlying volcanic rocks. 2) Metavolcanic rocks occurring mainly in the western and southern parts of the deposit, which were derived from pyroclastics of rhyolite and rhyodacite composition. Minor metabasic rocks are also present. 3) Thinly-layered phyllites, not exposed on the surface, are characterized by alteration of micas- and/or chlorite-rich with quartz-rich layers. They contain lens-shaped bodies of magnesite that, in spite of their tectonic contact, show gradual transitions into the surrounding phyllite. 
Granite forms small bodies cropping out at several localities in the Gemericum. The presence of large volumes of granite at depth was confirmed by numerous boreholes and geophysical measurements (Plančar et al. 1977). In the Dlhá Dolina Valley, the granite is not exposed on the surface, but was penetrated by more than 30 boreholes. The upper part of the granite body in one of the boreholes was represented by quartz albitites with cassiterite and $\mathrm{Nb}-\mathrm{Ta}$ mineralization (Malachovský et al. 1992). The Li-F albite-microcline and tourmaline granite occurs in the middle part and the porphyritic biotite-muscovite granite in the lower part of this hidden granite intrusion. The talc-magnesite body is lens-shaped and shows tectonic contacts with overlying laminated phyllites and underlying granite at the depth of approximately 215-760 $\mathrm{m}$ below the surface. It has a length of $3 \mathrm{~km}$ and thickness of up to $408 \mathrm{~m}$ (Kilík 1997). Besides magnesite and talc, it contains quartz, dolomite and chlorite.

\section{Petrography}

Detailed petrographic study was undertaken on 28 borehole samples of talc-carbonate-bearing rocks and granite. Talc forms either massive, cryptocrystalline clusters or thin veins and small nests in the magnesite-talc deposit. The second variety occurs also within intergranular spaces of magnesite, dolomite and quartz crystals. In addition to carbonates, accessory chlorite and pyrite are also present. Magnesite and dolomite are medium-grained and rarely form large crystals. If they do, these are cracked and penetrated by talc. Pyrite mostly occurs at contacts between talc and magnesite. Talc and carbonates are present also in phyllitic rocks above the magnesite-talc body.
Phyllitic rocks have mostly monotonous composition with quartz, white mica, chlorite and rare albite dominating. Locally present mafic rocks consist of epidote and actinolite. In some cases are also present small lenses of mono- to bi-mineralic epidote-amphibole rocks, resembling low-temperature skarns known from other localities of the Gelnica Group (Faryad and Peterec 1987). Relatively fresh (undeformed or weakly-deformed) granite is medium grained and consists of quartz, plagioclase, $\mathrm{K}$-feldspar, biotite and accessory muscovite. At its contact with the magnesite-talc body, granite is strongly mylonitized and contains a secondary assemblage of finegrained white mica associated with chlorite, phlogopite, clinozoisite and albite. Accessory tourmaline, showing an orientation parallel to the foliation, fluorapatite and dolomite are rather rare. Primary porphyroclastic quartz consists of subgrains and forms deformation lamellae. Some quartz porphyroclasts may contain inclusions of idiomorphic albite. Relics of plagioclase replaced by white mica and clinozoisite and small amounts of K-feldspar (orthoclase) are also present.

\section{Mineral compositions}

Minerals were analyzed using the raster electron microscope JEOL 6310 equipped by WDS detector at the Institute of Mineralogy and Petrology of the Carl-Franzens University, Graz (Austria) and by CamScan 4 at the Institute of Petrology and Structural Geology, Charles University, Prague (Czech Republic). The standards used included: jadeite $(\mathrm{Na})$, garnet $(\mathrm{Mg}, \mathrm{Fe})$, synthetic corundum (Al), quartz $(\mathrm{Si})$, adularia $(\mathrm{K})$, titanite $(\mathrm{Ca}, \mathrm{Ti})$ and rhodonite (Mn). Mineral analyses are given in Tables 1-4.

Tab. 1 Chemical compositions of carbonates (wt. \% and apfu)

\begin{tabular}{|c|c|c|c|c|c|c|c|c|c|c|c|c|}
\hline \multirow{3}{*}{$\begin{array}{l}\text { Sample* } \\
\text { Rock type } \\
\text { Mineral } \\
\end{array}$} & \multicolumn{4}{|c|}{$43 / 276$} & \multicolumn{5}{|c|}{$37 / 481$} & \multirow{3}{*}{\multicolumn{2}{|c|}{$\begin{array}{c}43 / 276 \\
\text { "soapstone“ } \\
\text { dolomite }\end{array}$}} & \multirow{3}{*}{$\begin{array}{c}45 / 337 \\
\text { granite } \\
\text { dolomite }\end{array}$} \\
\hline & \multicolumn{4}{|c|}{ „,Soapstone“ } & \multicolumn{5}{|c|}{ magnesite body } & & & \\
\hline & \multicolumn{2}{|c|}{ magnesite } & \multicolumn{2}{|c|}{ Fe-magnesite } & \multirow{2}{*}{$\begin{array}{c}\text { magnesite } \\
4.27\end{array}$} & \multicolumn{2}{|c|}{ Fe-magnesite } & \multicolumn{2}{|c|}{ dolomite } & & & \\
\hline $\mathrm{FeO}$ & 4.82 & 3.82 & 6.94 & 12.99 & & 10.63 & 10.80 & 2.30 & 2.41 & 0.86 & 1.86 & 4.58 \\
\hline $\mathrm{MnO}$ & 0.30 & 0.11 & 0.70 & 0.74 & 0.15 & 0.35 & 0.34 & 0.22 & 0.22 & 0.08 & 0.35 & 1.40 \\
\hline $\mathrm{MgO}$ & 43.57 & 44.69 & 41.89 & 36.93 & 44.33 & 39.32 & 39.17 & 20.72 & 20.48 & 22.00 & 20.49 & 18.75 \\
\hline $\mathrm{CaO}$ & 0.22 & 0.06 & 0.10 & 0.23 & 0.16 & 0.07 & 0.18 & 29.47 & 29.70 & 30.75 & 30.57 & 29.78 \\
\hline $\mathrm{CO}_{2}^{* *}$ & 50.87 & 51.24 & 50.48 & 48.91 & 51.21 & 49.70 & 49.72 & 47.28 & 47.27 & 46.17 & 45.43 & 45.25 \\
\hline Total & 99.78 & 99.92 & 100.11 & 99.80 & 100.12 & 100.08 & 100.21 & 99.99 & 100.07 & 99.86 & 98.70 & 99.76 \\
\hline $\mathrm{Fe}$ & 0.058 & 0.046 & 0.084 & 0.163 & 0.058 & 0.145 & 0.147 & 0.032 & 0.033 & 0.011 & 0.024 & 0.059 \\
\hline $\mathrm{Mn}$ & 0.004 & 0.001 & 0.009 & 0.009 & 0.002 & 0.005 & 0.005 & 0.003 & 0.003 & 0.001 & 0.005 & 0.018 \\
\hline $\mathrm{Mg}$ & 0.935 & 0.952 & 0.906 & 0.824 & 1.064 & 0.954 & 0.951 & 0.512 & 0.506 & 0.493 & 0.469 & 0.431 \\
\hline $\mathrm{Ca}$ & 0.003 & 0.001 & 0.002 & 0.004 & 0.003 & 0.001 & 0.003 & 0.524 & 0.528 & 0.495 & 0.503 & 0.492 \\
\hline Total & 1.000 & 1.000 & 1.000 & 1.000 & 1.126 & 1.105 & 1.106 & 1.071 & 1.070 & 1.000 & 1.000 & 1.000 \\
\hline
\end{tabular}




\subsection{Carbonates}

Most analysed carbonates correspond to magnesite with $\mathrm{X}_{\mathrm{Mg}}=\mathrm{Mg} /(\mathrm{Mg}+\mathrm{Ca}+\mathrm{Mn})=0.99-1.00$ and low $\mathrm{Ca}$ and Mn (0.001-0.004 atoms per formula unit, apfu). Siderite $\left(\mathrm{FeCO}_{3}\right)$ component increases from 4.82 wt. \% in magnesite to $6.94-12.99$ wt. $\% \mathrm{FeCO}_{3}$ in Fe-magnesite. The main substitution occurs between $\mathrm{Fe}$ and $\mathrm{Mg}$, whereby $\mathrm{MgO}$ decreases from 41.89 to 36.93 wt. \%. Dolomite associated with magnesite has 20.5-22.0 wt. \% MgO and 29.7-30.7 wt. \% $\mathrm{CaO}$ (Tab. 1) and $\mathrm{X}_{\mathrm{Fe}}=(\mathrm{Fe} /(\mathrm{Fe}+$ $\mathrm{Mg}+\mathrm{Ca}+\mathrm{Mn})=0.006-0.015$. Chemical analyses show only trace amounts of $\mathrm{Fe}$ and $\mathrm{Mn}$. Dolomite analyzed in granite is relatively rich in $\mathrm{Fe}\left(\mathrm{X}_{\mathrm{Fe}}=0.03\right)$ but has lower $\mathrm{MgO}$ (18.7 wt. \%) compared to that occurring in magnesite. Carbonates in surrounding phyllitic rocks are mostly rich in $\mathrm{Fe}$ and have composition ranging from $\mathrm{Fe}$ magnesite/dolomite to ankerite and siderite.

\subsection{Talc}

Microprobe analyses of talc are listed in Tab. 2. It has nearly an ideal composition with $\mathrm{X}_{\mathrm{Mg}}=\mathrm{Mg} /(\mathrm{Fe}+\mathrm{Mg})$ $=0.99$ and $\mathrm{Al} \leq 0.03 \mathrm{apfu}$. There are no compositional variations of talc among different textural varieties.

\subsection{Chlorite}

The Mg-rich chlorite $\left(\mathrm{X}_{\mathrm{Mg}}=\mathrm{Mg} /(\mathrm{Mg}+\mathrm{Fe})=0.93-0.96\right)$ is associated with talc. By contrast, chlorite occurring together with phengite and phlogopite in the granite has relatively high $\mathrm{Fe}$ contents $\left(\mathrm{X}_{\mathrm{Mg}}=0.88-0.89\right)$. Chlorite associated with talc has generally low $\mathrm{Al} / \mathrm{Si}(0.68-0.72)$ compared to that occurring on its own or in the metagranite $(\mathrm{Al} / \mathrm{Si}=0.74-0.80)(\mathrm{Tab} .3)$.

\subsection{Micas}

Metamorphic white mica analysed in metagranite corresponds to phengite with $\mathrm{Si}=3.32-3.34 \mathrm{apfu}$ (Tab. 4) and $\mathrm{Na} /(\mathrm{Na}+\mathrm{K})=0.047-0.063$. It occurs together with phlogopite, chlorite, tourmaline and quartz. Phlogopite both from metagranite and that associated with Mg-rich chlorite and talc from talc-rich aggregates in the deposit has $\mathrm{X}_{\mathrm{Mg}}=0.94$ (Tab. 4).

\subsection{Other minerals}

Accessory apatite with relatively high fluorine content $(\mathrm{F}=3.8 \%)$ is present in granite as a part of an assemblage with quartz, muscovite, chlorite and tourmaline. It was recorded also in the talc-carbonate rock. Analyzed tourmaline from granite is dravite with $\mathrm{X}_{\mathrm{Mg}}=0.86$.

\section{Metamorphic conditions}

\subsection{Previous studies}

As discussed in the introduction, metamorphism of both Variscan and Alpine ages produced greenschist-facies minerals that are difficult to distinguish in the area. Detailed petrological studies indicated relatively lower pressure of $4-6$ kbar at $350-499^{\circ} \mathrm{C}$ for the Gelnica (Faryad, 1995 ) and higher pressure of 6-10 kbar at 400-450 ${ }^{\circ} \mathrm{C}$ for the Rakovec Group, the latter with metabasites

Tab. 2 Chemical composition of talc (wt. \% and apfu)

\begin{tabular}{|c|c|c|c|c|c|c|c|c|}
\hline \multirow{2}{*}{$\begin{array}{l}\text { Sample } \\
\text { Rock type } \\
\end{array}$} & \multicolumn{3}{|c|}{$37 / 481$} & $43 / 276$ & \multicolumn{4}{|c|}{$45 / 288$} \\
\hline & \multicolumn{3}{|c|}{ magnesite body } & „soapstone" & \multicolumn{4}{|c|}{ magnesite body } \\
\hline $\mathrm{SiO}_{2}$ & 62.10 & 61.93 & 62.15 & 61.89 & 63.65 & 62.48 & 62.26 & 62.95 \\
\hline $\mathrm{TiO}_{2}$ & 0.00 & 0.00 & 0.00 & 0.00 & 0.04 & 0.01 & 0.00 & 0.00 \\
\hline $\mathrm{Al}_{2} \mathrm{O}_{3}$ & 0.21 & 0.22 & 0.04 & 0.26 & 0.27 & 0.20 & 0.24 & 0.54 \\
\hline $\mathrm{FeO}$ & 1.08 & 1.12 & 0.65 & 1.58 & 1.13 & 0.78 & 0.66 & 0.92 \\
\hline $\mathrm{MnO}$ & 0.00 & 0.02 & 0.00 & 0.02 & 0.08 & 0.03 & 0.01 & 0.00 \\
\hline $\mathrm{MgO}$ & 30.77 & 31.36 & 30.76 & 28.98 & 30.17 & 31.09 & 30.83 & 31.24 \\
\hline \multirow[t]{2}{*}{ Total } & 94.16 & 94.65 & 93.57 & 92.73 & 95.34 & 94.59 & 94.00 & 95.65 \\
\hline & \multicolumn{8}{|c|}{ Calculated on the basis of $11(\mathrm{O})$} \\
\hline $\mathrm{Si}$ & 3.98 & 3.95 & 4.01 & 4.00 & 4.06 & 3.98 & 4.00 & 3.97 \\
\hline $\mathrm{Ti}$ & 0.00 & 0.00 & 0.00 & 0.00 & 0.00 & 0.00 & 0.00 & 0.00 \\
\hline $\mathrm{Al}$ & 0.02 & 0.02 & 0.00 & 0.01 & 0.01 & 0.02 & 0.00 & 0.03 \\
\hline $\mathrm{Fe}$ & 0.06 & 0.06 & 0.04 & 0.09 & 0.06 & 0.04 & 0.04 & 0.05 \\
\hline $\mathrm{Mn}$ & 0.00 & 0.00 & 0.00 & 0.00 & 0.00 & 0.00 & 0.00 & 0.00 \\
\hline $\mathrm{Mg}$ & 2.94 & 2.98 & 2.96 & 2.79 & 2.78 & 2.96 & 2.95 & 2.94 \\
\hline
\end{tabular}


Tab. 3 Chemical composition of chlorite (wt. \% and apfu)

\begin{tabular}{|c|c|c|c|c|c|c|c|c|c|c|}
\hline \multirow{3}{*}{$\begin{array}{l}\text { Sample } \\
\text { Rock type } \\
\mathrm{SiO}_{2}\end{array}$} & \multicolumn{3}{|c|}{$43 / 276$} & \multicolumn{2}{|c|}{$45 / 288$} & \multicolumn{2}{|c|}{$45 / 337$} & \multicolumn{3}{|c|}{$37 / 481$} \\
\hline & \multicolumn{3}{|c|}{ „soapstone“ } & \multicolumn{2}{|c|}{ magnesite body } & \multicolumn{2}{|c|}{ granite } & \multicolumn{3}{|c|}{ magnesite body } \\
\hline & 32.12 & 31.42 & 32.04 & 32.39 & 32.12 & 31.04 & 30.43 & 30.11 & 30.04 & 29.95 \\
\hline $\mathrm{TiO}_{2}$ & 0.02 & 0.04 & 0.03 & 0.01 & 0.06 & 0.02 & 0.07 & 0.04 & 0.00 & 0.03 \\
\hline $\mathrm{Al}_{2} \mathrm{O}_{3}$ & 18.56 & 19.10 & 17.83 & 20.27 & 20.03 & 19.85 & 20.07 & 20.90 & 20.52 & 20.78 \\
\hline $\mathrm{FeO}$ & 4.14 & 4.44 & 3.98 & 3.31 & 3.10 & 6.01 & 6.52 & 2.66 & 2.79 & 2.89 \\
\hline $\mathrm{MnO}$ & 0.07 & 0.05 & 0.08 & 0.00 & 0.02 & 0.04 & 0.08 & 0.00 & 0.05 & 0.03 \\
\hline $\mathrm{MgO}$ & 31.10 & 30.75 & 30.94 & 31.27 & 31.27 & 28.72 & 27.49 & 32.87 & 32.53 & 32.62 \\
\hline $\mathrm{CaO}$ & 0.01 & 0.01 & 0.03 & 0.02 & 0.00 & 0.03 & 0.07 & 0.03 & 0.10 & 0.00 \\
\hline $\mathrm{Na}_{2} \mathrm{O}$ & 0.01 & 0.03 & 0.02 & 0.02 & 0.01 & 0.01 & 0.03 & 0.00 & 0.03 & 0.00 \\
\hline $\mathrm{K}_{2} \mathrm{O}$ & 0.03 & 0.00 & 0.01 & 0.02 & 0.02 & 0.05 & 0.04 & 0.02 & 0.01 & 0.03 \\
\hline Total & 86.06 & 85.84 & 84.96 & 87.31 & 86.63 & 85.77 & 84.80 & 86.63 & 86.07 & 86.33 \\
\hline \multicolumn{11}{|c|}{ Calculated on the basis of $28(\mathrm{O})$} \\
\hline $\mathrm{Si}$ & 6.179 & 6.064 & 6.241 & 6.125 & 6.116 & 6.060 & 6.036 & 5.772 & 5.802 & 5.808 \\
\hline $\mathrm{Al}^{\mathrm{IV}}$ & 1.821 & 1.936 & 1.759 & 1.875 & 1.884 & 1.940 & 1.964 & 2.228 & 2.198 & 2.192 \\
\hline $\mathrm{Al}^{\mathrm{VI}}$ & 2.387 & 2.408 & 2.334 & 2.643 & 2.610 & 2.627 & 2.728 & 2.386 & 2.365 & 2.404 \\
\hline $\mathrm{Ti}$ & 0.003 & 0.006 & 0.004 & 0.001 & 0.009 & 0.003 & 0.010 & 0.006 & 0.000 & 0.004 \\
\hline $\mathrm{Fe}^{2+}$ & 0.666 & 0.717 & 0.648 & 0.523 & 0.494 & 0.981 & 1.082 & 0.417 & 0.440 & 0.454 \\
\hline $\mathrm{Mn}$ & 0.011 & 0.008 & 0.013 & 0.000 & 0.003 & 0.007 & 0.013 & 0.000 & 0.008 & 0.005 \\
\hline $\mathrm{Mg}$ & 8.920 & 8.848 & 8.984 & 8.816 & 8.876 & 8.359 & 8.130 & 9.180 & 9.153 & 9.126 \\
\hline $\mathrm{Ca}$ & 0.002 & 0.002 & 0.006 & 0.004 & 0.000 & 0.006 & 0.015 & 0.006 & 0.020 & 0.000 \\
\hline $\mathrm{Na}$ & 0.004 & 0.011 & 0.008 & 0.007 & 0.004 & 0.004 & 0.012 & 0.000 & 0.011 & 0.000 \\
\hline $\mathrm{K}$ & 0.007 & 0.000 & 0.002 & 0.005 & 0.005 & 0.012 & 0.010 & 0.005 & 0.002 & 0.007 \\
\hline $\mathbf{X}_{\mathrm{Mg}}$ & 0.93 & 0.93 & 0.93 & 0.94 & 0.95 & 0.89 & 0.88 & 0.96 & 0.95 & 0.95 \\
\hline
\end{tabular}

containing $\mathrm{Na}-\mathrm{Ca}$ amphibole of taramite composition (Hovorka et al. 1988; Faryad and Bernhardt 1996). Alpine metamorphic conditions, obtained for rocks not affected by the Variscan metamorphic event (Permian granite and Upper Palaeozoic cover sequences), yielded pressures of 6-7 kbar at $350-400{ }^{\circ} \mathrm{C}$ (Faryad and Dianiška 1999). The rocks in Dlhá Dolina were additionally affected by contact metamorphism, which produced spotted phyllites with dark clusters of chlorite (up to $1 \mathrm{~cm}$ across) that overgrow the thin sedimentary layers and foliation in phyllitic rocks. Malachovský et al. (1992) described different varieties of metasomatic rocks (albitite and lowtemperature skarns) as well as rare-metal mineralization related to the granite magmatism. With exception of rarely observed relics and pseudomorphs of mica after andalusite and cordierite (Dianiška 1983; Faryad 1992), high-T minerals are not present in phyllitic rocks at the granite contact. The scarcity of these minerals is probably due to: 1) small size of granite bodies that could have produced only narrow HT contact aureoles in the host phyllites, and 2) mechanical anisotropy between granite and surrounding phyllites that was important for the formation of mylonite zones during at the Alpine tectonic event. Degree of recrystallization and mineral transformation during Alpine event depends on deformation along the mylonitic zones. Thus entire parts of large tectonic
Tab. 4 Chemical compositions of micas from the granite 45/337 (wt. $\%$ and apfu)

\begin{tabular}{|c|c|c|c|c|c|c|}
\hline \multirow{2}{*}{$\frac{\text { Mineral }}{\mathrm{SiO}_{2}}$} & \multicolumn{4}{|c|}{ phengite } & \multicolumn{2}{|c|}{ phlogopite } \\
\hline & 51.87 & 50.47 & 51.02 & 51.87 & 44.13 & 43.79 \\
\hline $\mathrm{TiO}_{2}$ & 0.01 & 0.02 & 0.03 & 0.01 & 0.00 & 0.02 \\
\hline $\mathrm{Al}_{2} \mathrm{O}_{3}$ & 31.88 & 30.65 & 30.38 & 31.88 & 12.48 & 12.75 \\
\hline $\mathrm{FeO}$ & 0.55 & 0.36 & 0.50 & 0.55 & 2.64 & 2.72 \\
\hline $\mathrm{MnO}$ & 0.08 & 0.00 & 0.01 & 0.08 & 0.02 & 0.06 \\
\hline $\mathrm{MgO}$ & 2.91 & 2.94 & 3.32 & 2.91 & 24.37 & 23.84 \\
\hline $\mathrm{CaO}$ & 0.02 & 0.05 & 0.07 & 0.02 & 0.01 & 0.01 \\
\hline $\mathrm{Na}_{2} \mathrm{O}$ & 0.43 & 0.36 & 0.32 & 0.43 & 0.12 & 0.08 \\
\hline $\mathrm{K}_{2} \mathrm{O}$ & 9.60 & 10.19 & 10.02 & 9.68 & 10.01 & 10.18 \\
\hline \multirow[t]{2}{*}{ Total } & 97.35 & 95.04 & 95.67 & 97.43 & 93.78 & 93.45 \\
\hline & \multicolumn{6}{|c|}{ Calculated on the basis of $11(\mathrm{O})$} \\
\hline $\mathrm{Si}$ & 3.326 & 3.329 & 3.341 & 3.325 & 3.125 & 3.120 \\
\hline $\mathrm{Ti}$ & 0.000 & 0.000 & 0.001 & 0.000 & 0.000 & 0.000 \\
\hline $\mathrm{Al}$ & 2.410 & 2.384 & 2.346 & 2.409 & 0.520 & 0.570 \\
\hline $\mathrm{Fe}_{\mathrm{t}}$ & 0.029 & 0.020 & 0.027 & 0.029 & 0.155 & 0.160 \\
\hline $\mathrm{Mn}$ & 0.004 & 0.000 & 0.001 & 0.004 & 0.000 & 0.005 \\
\hline $\mathrm{Mg}$ & 0.278 & 0.289 & 0.324 & 0.278 & 2.570 & 2.530 \\
\hline $\mathrm{Ca}$ & 0.001 & 0.004 & 0.005 & 0.001 & 0.000 & 0.000 \\
\hline $\mathrm{Na}$ & 0.053 & 0.046 & 0.041 & 0.053 & 0.450 & 0.475 \\
\hline K & 0.786 & 0.858 & 0.838 & 0.792 & 0.010 & 0.010 \\
\hline
\end{tabular}


blocks of granite are relatively fresh and may show only local equilibria among their rock-forming minerals.

\subsection{Pressure and temperature estimates and discussion}

Minerals present in metasedimentary and metavolcanic rocks around the magnesite-talc deposit suggest that temperatures both during Variscan metamorphism and granite intrusion did not exceed $450{ }^{\circ} \mathrm{C}$. The hypotheses about the talc formation as a result of Variscan regional metamorphism (Radvanec et al. 2004) or of contact-metasomatic processes due to the granite intrusion (Malachovský 1992; Kilík 1997) can be therefore tested by the combination of this preliminary temperature estimate and study of textures developed in the carbonate-talc rocks. Quantitative carbonate phase analysis in the dolomite-magnesite rocks from the Dlhá Dolina Valley (Turanová et al. 1997) indicated that steatitized parts have high dolomite/magnesite ratios compared to the talc-free parts. This observation, together with the absence of calcite in the talc-bearing assemblage, suggests preferential partitioning of magnesite in the talc-forming reaction:

$$
3 \mathrm{Mgs}+4 \mathrm{SiO}_{2}+\mathrm{H}_{2} \mathrm{O}=\mathrm{Tc}+3 \mathrm{CO}_{2}
$$

The $\mathrm{T}-\mathrm{X}_{\mathrm{CO}_{2}}$ and $\mathrm{P}-\mathrm{X}_{\mathrm{CO}_{2}}$ variations for this reaction were examined using the TWEEQ software (Berman 1996). Since talc has uniform composition and variation of $\mathrm{X}_{\mathrm{Mg}}$ in magnesite is not significant, the results of these calculations indicated $\mathrm{X}_{\mathrm{CO}_{2}}=0.8$ as the most reasonable value for this reaction (Fig. 2a-b). Assuming temperature of $400 \pm 20^{\circ} \mathrm{C}$, based on the presence of only chlorite in phyllites and actinolite in metabasites, pressures of about 1 kbar can be deduced from the $\mathrm{X}_{\mathrm{CO}_{2}}$ isopleths of reaction (1) in the P-T field (Fig. 2c). Such pressures were estimated for contact metamorphism and hence for the depth of granite emplacement in the central part of the Gemericum by using amphibole-garnet-clinopyroxene thermobarometry from skarn in the vicinity of Zlatá Idka (Faryad and Peterec 1987). It should be emphasized that Mg-carbonate rocks with the same stratigraphic position and having underwent Variscan regional metamorphism of similar $\mathrm{P}-\mathrm{T}$ conditions are present also near Mníšek/ Hnilec (Borehole MPV). As there is no evidence of contact metamorphism and metasomatism at this locality, the Mg-carbonate is free of talc. The formation of talc in Dlhá Dolina during granite magmatism is supported by the local extent of steatitization of magnesite that reflects variation in intensity of hydrothermal and metasomatic alteration observed also in surrounding rocks as well as in the upper parts of the granite body.

In order to estimate the $\mathrm{P}-\mathrm{T}$ conditions for the mylonitized granite (and hence those of the Alpine metamorphism), the mineral assemblage quartz + muscovite
+ chlorite + phlogopite was used to calculate equilibrium curve of the reaction:

$$
\begin{aligned}
& \text { clinochlore }+4 \text { celadonite }=\text { muscovite }+3 \text { phlogopite } \\
& +7 \text { quartz }+4 \mathrm{H}_{2} \mathrm{O}
\end{aligned}
$$

In addition, $\mathrm{P}-\mathrm{T}$ section approach using the Perple_X software (Connolly 2005) and the internally consistent thermodynamic dataset of Holland and Powell (1998: 2001 upgrade) was applied to model the Alpine P-T conditions for the mylonite. As mylonite contains relics of K-feldspar, the bulk rock composition used in the thermodynamic modelling was calculated by a combination of modal amounts and microprobe analyses of the phases present in the mylonite matrix. Equilibrium P-T conditions of the reaction (2) were calculated using the programs Ax and THERMOCALC (Holland and Powell
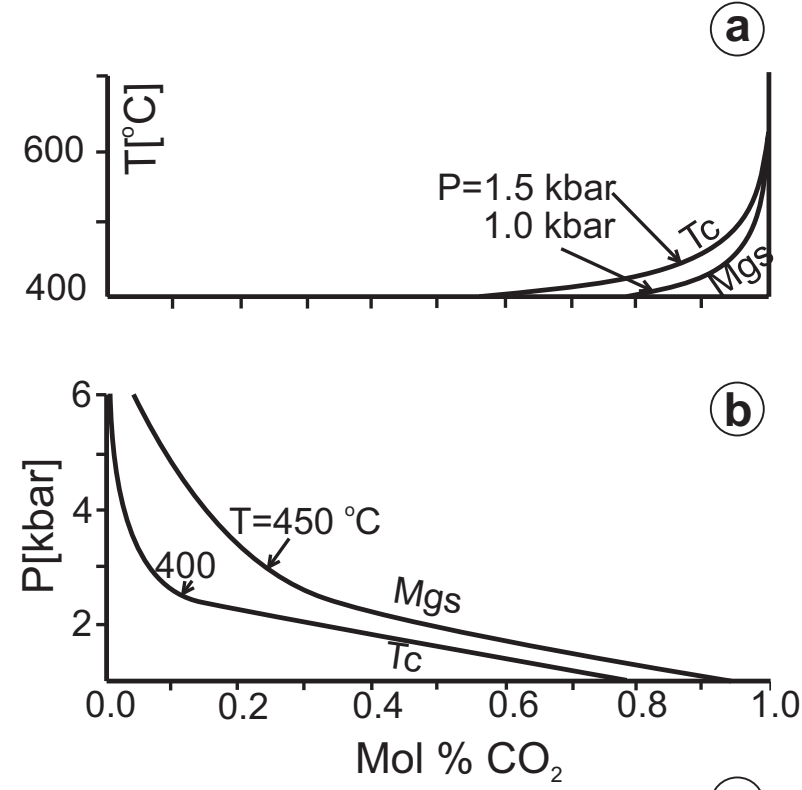

(c)

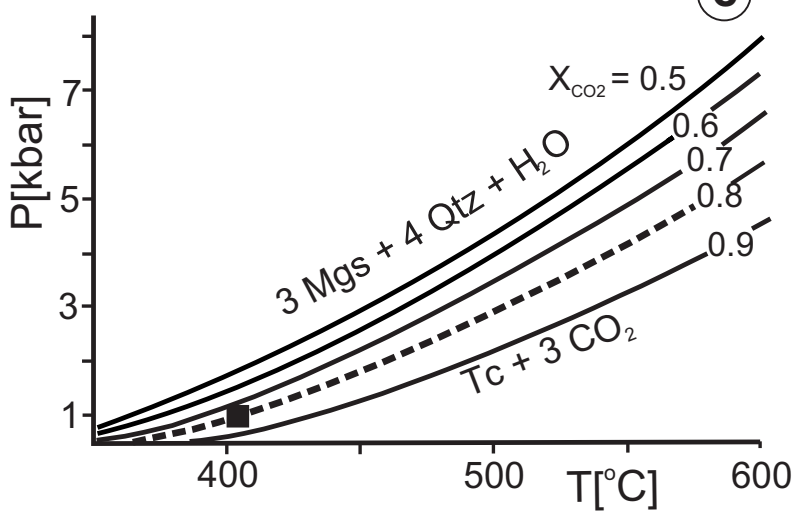

Fig. $2 \mathrm{P}-\mathrm{T}-\mathrm{X}$ relations for the talc-forming reaction $(3 \mathrm{Mgs}+4 \mathrm{Qtz}$ $+\mathrm{H}_{2} \mathrm{O}=\mathrm{Tc}+3 \mathrm{CO}_{2}$ ) obtained by TWEEQ program (Berman 1996). a) $\mathrm{T}-\mathrm{X}_{\mathrm{CO}_{2}}$ diagram calculated for pressures of 1 and $1.5 \mathrm{kbar}$. b) $\mathrm{P}-\mathrm{X}_{\mathrm{CO}_{2}}$ diagram constructed for 400 and $450{ }^{\circ} \mathrm{C}$. c) Equilibrium curves of talcforming reaction at different $\mathrm{X}_{\mathrm{CO}_{2}}$. Mineral abbreviations used in the figures are after Kretz (1983). 
1998). This reaction is strongly pressure- and temperature-dependent and gives pressure of 4-8 $\mathrm{kbar}$ in the temperature range of $400-450{ }^{\circ} \mathrm{C}$. The equilibrium curve of this reaction can be combined with phengite barometry (Massonne and Schreyer 1987), which was experimentally developed for the assemblage of phengite with phlogopite in the presence of K-feldspar. Intersection of $\mathrm{Si}$-isopleths in phengite with $3.32-3.33$ apfu yields pressure of 6.6-7.4 kbar and $430-440{ }^{\circ} \mathrm{C}$ (Fig. 3).

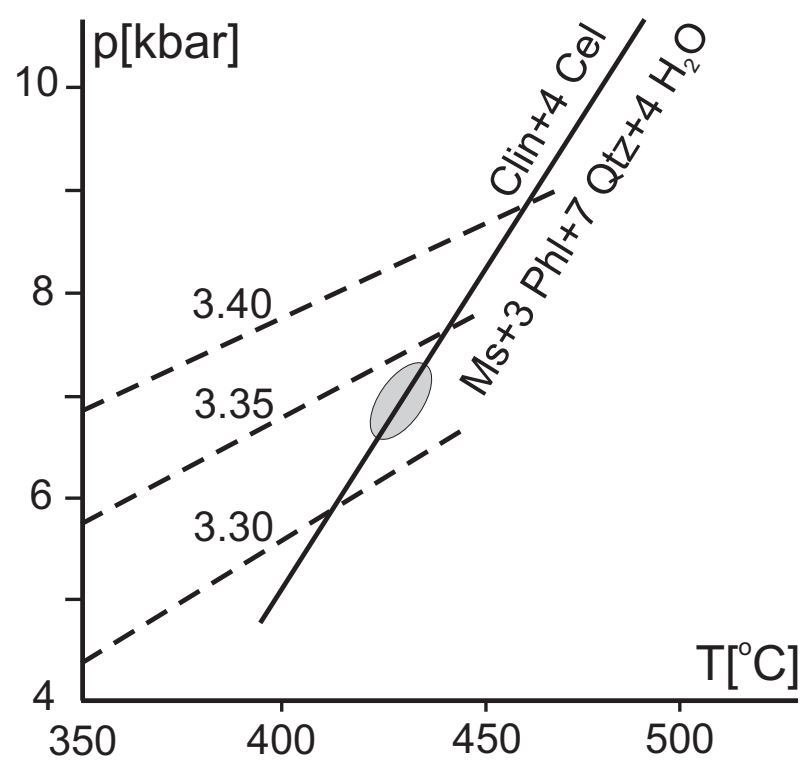

Fig. 3 P-T conditions of Alpine metamorphism estimated using metamorphic minerals in the metagranite. The equilibrium curve for the reaction Clin $+4 \mathrm{Cel}=\mathrm{Ms}+3 \mathrm{Phl}+7 \mathrm{Qtz}+4 \mathrm{H}_{2} \mathrm{O}$ was calculated by THERMOCALC (Holland and Powell 1998). Isopleths of Si for white mica are after Massonne and Schreyer (1987).

Figure 4 shows $\mathrm{P}-\mathrm{T}$ section calculated for the mylonite, where the matrix mineral assemblage of phengitic muscovite, biotite (phlogopite), clinozoisite, plagioclase, and quartz corresponds to the three-variant field giving a wide range of temperatures $\left(350-450^{\circ} \mathrm{C}\right)$ and pressures $(6.3-6.7$ kbar). However, the isopleths of $\mathrm{Si}$ in the analyzed phengitic muscovite $(\mathrm{Si}=3.32 \mathrm{apfu})$ have helped to constrain the pressure to $6-7 \mathrm{kbar}$ at $400 \pm 15^{\circ} \mathrm{C}$. Considering the position of the equilibrium curve of reaction (2) and $\mathrm{Si}$ isopleths in Figs 3 and 4, the pressure of $7 \mathrm{kbar}$ at $420{ }^{\circ} \mathrm{C}$ can be interpolated for the Alpine metamorphic overprint in this area. The $\mathrm{P}-\mathrm{T}$ conditions, obtained both by the reaction (1) and P-T section with combination of Si-isopleths in phengite, are consistent with those obtained by Faryad and Dianiška (1999) for Alpine metamorphism in the garnet-bearing assemblage in the metagranite.

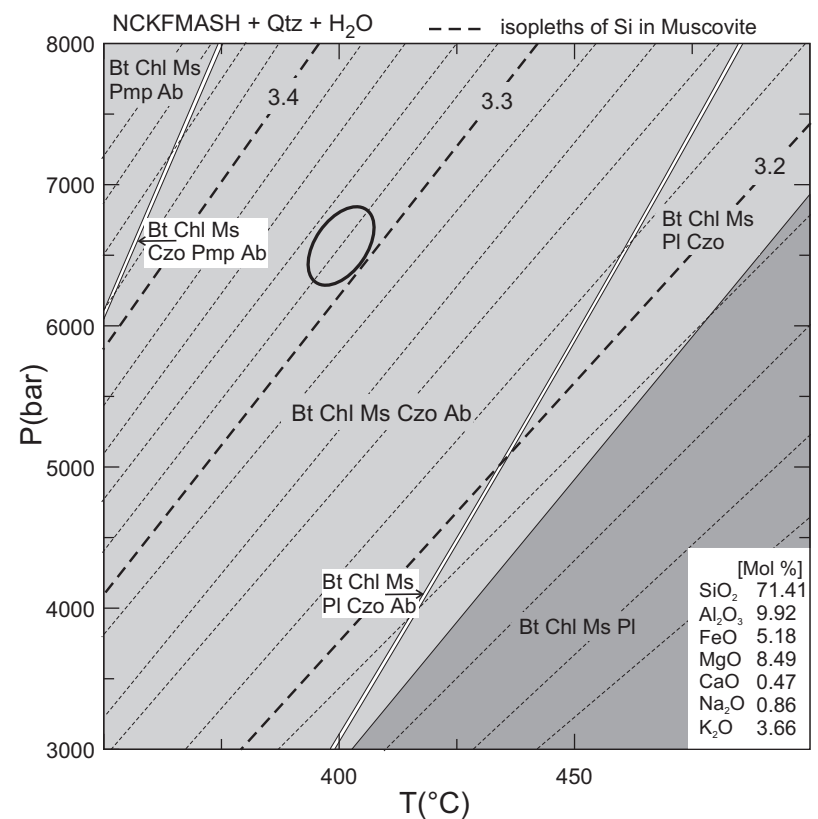

Fig. 4 P-T section constrained by the Perple_X software (Connolly 2005) for Alpine mineral assemblage in the mylonitized granite from the Dlhá Dolina. Ellipse shows pressure conditions based on Si isopleths in phengitic muscovite at temperature of $400 \pm 15^{\circ} \mathrm{C}$.

\section{Conclusions}

Field and textural relations in the talc-magnesite deposit confirm syn-sedimentary origin of $\mathrm{Ca}-\mathrm{Mg}$ carbonate rocks that were converted to crystalline magnesite during Variscan regional metamorphism. Formation of some talc during this regional metamorphism cannot be excluded; however the main talc-forming process was related to metasomatic alteration related to the Permian granite magmatism. The granite intrusion resulted in heating and hydrothermal-metasomatic alteration of the country rocks (Malachovský et al. 1992; Kilík 1997).

The reaction responsible for the talc formation (magnesite + quartz $+\mathrm{H}_{2} \mathrm{O}=$ talc $+\mathrm{CO}_{2}$ ) was used to estimate the $\mathrm{P}-\mathrm{T}-\mathrm{X}$ conditions during this thermal event. The results indicate transformation of magnesite at pressure of c. $1 \mathrm{kbar}$, temperature of $c .430{ }^{\circ} \mathrm{C}$ and $\mathrm{X}_{\mathrm{CO}_{2}}=0.8$. Contact zones between granite and the surrounding phyllites and partly steatitized magnesite were due to their mechanical anisotropy affected by mylonitization during the Alpine tectono-metamorphic event. The $\mathrm{P}-\mathrm{T}$ conditions of the Alpine metamorphism were estimated from mineral assemblages present in the metagranite. Using the composition of phengitic muscovite (coexisting with chlorite and phlogopite) with maximum $\mathrm{Si}=3.34 \mathrm{apfu}$, the pressure of $7 \mathrm{kbar}$ at temperature of $c .430{ }^{\circ} \mathrm{C}$ was calculated. These $\mathrm{P}-\mathrm{T}$ conditions were confirmed also by the $\mathrm{P}-\mathrm{T}$ section constructed for phlogopite- and clinozoisite-bearing assemblages in the mylonitized granite. 
Acknowledgments. This work was part of the diploma work of KP and supported by the research project (GAUK 373/2004) at Charles University and by MSM0021620855. I. Dianiška is acknowledged for discussion during preparation of this paper. M. Janák and an anonymous reviewer are thanked for their detailed comments and suggestions to the manuscript. V. Janoušek is thanked for the editorial handling.

\section{References}

Bajaník S, Hanzel V, IvaničKa J, Mello J, Pristaš J, ReichWAlder P, Snopko L, VozÁr J, VozÁRovÁ A (1983) Explanations to the geological map of the Slovak Ore Mountains 1:50 000. Dionýz Štúr Institute of Geology, Bratislava, pp 1-224

BERMAN RG (1996) TWEEQ (version 2.02), Thermobarometry with estimation of equilibration state, http://gsc.nrcan.gc.ca/sw/twq_e.php

Connolly JAD (2005) Computation of phase equilibria by linear programming: a tool for geodynamic modeling and its application to subduction zone decarbonation. Earth Planet Sci Lett 236: 524-541

DiAnišKA I (1983) Endo- and exo-contact alterations of granite and surrounding rocks from the Gemericum. Unpublished PhD thesis, Comenius University Bratislava, pp 1-231 (in Slovak)

FARYAD SW (1992) Thermal overprint in the early Paleozoic sequences of Gemericum (Western Carpathians). Special Volume of the IGCP Project No 276, Dionýz Štúr Institute of Geology, Bratislava, pp 49-56

FARYAD SW (1995) Stanovenie P-T podmienok metamorfózy horninových komplexov staršieho paleozoika gemerika. Miner Slov 27: 9-19

FARYAD SW, BERnhardt HJ (1996) Taramite-bearing metabasites from Rakovec (Gemeric Unit, the Western Carpathians). Geol Zbor Geol Carpath 47: 384-392

FARYAD SW, DiANIŠKA I (1989) Garnet from granitoids of the Spisško-gemerské Rudohorie Mts. Geol Zbor Geol Carpath 40: 715-734

FARYAD SW, DiANIŠKA I (1999) Alpine overprint in the early Paleozoic of the Gemericum. Miner Slov 31: 485-490

FARyad SW, Peterec D (1987) Manifestations of skarn mineralization in the eastern part of the Spišsko-gemerské Rudohorie Mts. Geol Zbor Geol Carpath 38: 111-128

GreCUla P (1982) Gemerikum - a segment rifting basin of the Paleotethys. Alfa, Bratislava, pp 1-263

Holland TJB, Powell R (1998) An internally consistent thermodynamic data set for phases of petrological interest. J Metamorph Geol 16: 309-334
Holland TJ B, Powell R (2001) Calculation of phase relations involving haplogranitic melts using an internally consistent thermodynamic dataset. J Petrol 42, 673-683.

Hovorka D, Ivan P, Jilemnická L, Spišiak J (1988) Petrology and geochemistry of metabasalts from Rakovec (Paleozoic of Gemeric Group, Inner Western Carpathians). Geol Zbor Geol Carpath 39: 395-425

Kı́ík J (1997) Geological characteristics from talc deposit Gemerská Poloma-Dlhá Dolina. Acta Montanistica Slovaca 2 : $71-80$

Kovách A, Svinger E, Grecula P (1986) Rb-Sr isotope ages of granitoid rocks from the Spišsko-Gemerské Rudohorie Mts. Miner Slov 18: 1-14

KRETz R (1983) Symbols for rock-forming minerals. Amer Miner 68: 277-279

Malachovský P, Turanová L, Dianiška I (1992) Final report of mineral exploration from Gemerska Poloma. Slovak Geological Survey, Spišská Nová Ves (Archive), pp 1-132

Massone HJ, Schreyer W (1987) Phengite geobarometry based on the limiting assemblage with K-feldspar, phlogopite, and quartz. Contrib Mineral Petrol 96: 212-224

Plančár J, Fillo M, Šefara J, Snopko L, Klinec A (1977) Geophysical and geological interpretation of ore deposits and magnetic anomaly in the Slovak Ore Mountains. Západné Karpaty, Geológia 2: 7-114

Poller U, Broska I, Finger F, Uher P, Janák M (2000) Permian age of Gemeric granites constrained by single zircon and EMPA monazite dating. Miner Slov 32: 189-190

Radvanec M, Kodera P, Prochaska W (2004) Mg replacement at the Gemerská Poloma talc-magnesite deposit, Western Carpathians, Slovakia. Acta Petrol Sinica 20: $773-790$

SNOPKO L (1967) Lithological characteristics of the Gelnice series. Záp. Karpaty 7: 103-151

Turanová L, Turan J, Kilík J (1997) Mineralization of a magnesite-talc deposit Gemerská Poloma (Spišsko-Gemerské Rudohorie Mts). Acta Geol Univ Com 52: 5-13

VARGA I (1973) Mineralnye associacii regionalnovo metamorfizma a ich zonalnost' v Spišsko-Gemerskom rudohorii. Min Slov 5: 115-134

VRÁNA S (1964) Chloritoid and kyanite zone of Alpine metamorphism on the boundary of the Gemerides and Veporides (Slovakia). Krystalinikum 2: 45-53

VRÁNA S (1980) Newly formed Alpine garnets in metagranitoids of the Veporides in relation to the structure of the central zone of the West Carpathians. Cas Mineral Geol 25: 41-54 